\title{
GAMBARAN GULA DARAH DARAH PADA REMAJA OBES DI MINAHASA
}

\author{
${ }^{1}$ Fitria Angela Umar \\ ${ }^{2}$ Widdhi Bodhi \\ ${ }^{2}$ Billy J. Kepel
}

\author{
${ }^{1}$ Kandidat Skripsi Fakultas Kedokteran Universitas Sam Ratulangi Manado \\ ${ }^{2}$ Bagian Kimia Fakultas Kedokteran Universitas Sam Ratulangi Manado
}

\begin{abstract}
Obesity is an accumulation of excessive fat that can induce insulin resistance. If that happen, the blood sugar inside body will increase (hyperglycemia). Adolesence is impressionable to globalization of the high - fat and low - fiber diets such fast food or junk food. This reason of increasing prevalence of obesity and risk of diabetes mellitus. Blood sugar examination important to prevent the risk of obesity. Population in this research is all adolescence between 13 to 18 years old at Minahasa. Total of sample quantity are 54 students, which consist of 11 boys and 43 girls. Results that 4 girls $(7,4 \%)$ are hyperglycemia. 11 boys and 39 girls with normal blood sugar. Mean and standar deviation of blood sugar is $82,2+21$. This number can be effected by genetics, diets and physical activity of adolescence.
\end{abstract}

Keywords: blood sugar, obesity, adolescence.

Obesitas merupakan akumulasi lemak berlebihan yang dapat menyebabkan terjadinya resistensi insulin. Bila hal ini terjadi, maka gula darah di dalam tubuh meningkat (hiperglikemia). Remaja gampang terpengaruh oleh globalisasi pada pola makan tinggi lemak dan rendah serat seperti fast food atau junk food. Sehingga meningkatkan prevalensi obesitas dan resiko terhadap diabetes mellitus. Populasi dalam penelitian ini adalah remaja obes usia 13 sampai 18 tahun yang berada di Minahasa. Jumlah sampel dalam penelitian ini sebanyak 54 orang, yang terdiri dari 11 laki-laki dan 43 perempuan. Penelitian ini didapatkan 4 siswa perempuan $(7,4 \%)$ mengalami hiperglikemia. Sebanyak 11 siswa laki-laki dan 39 siswa perempuan mempunyai kadar gula darah dalam batas normal. Nilai rerata dan standar deviasi gula darah puasa adalah $82,2+21$. Hasil penelitian dapat disebabkan faktor genetik, pola makan, dan aktivitas fisik remaja yang mudah terpengaruh dengan globalisasi.

Kata kunci: gula darah, obesitas, remaja.

Salah satu tantangan terbesar kesehatan masyarakat pada abad 21 adalah epidemi penyakit degeneratif yang berhubungan dengan peningkatan dramatis obesitas. Peningkatan prevalensi obesitas ini di negara berkembang terjadi karena modernisasi gaya hidup. ${ }^{1}$ Perkiraan 210 juta penduduk Indonesia thn 2000 jumlah penduduk yang overweight mencapai 76.7 juta (17.5\%) dan pasien obesitas berjumlah lebih dari 9.8 juta (4.7\%). Berdasarkan data tersebut, maka Overweight dan Obesitas di Indonesia telah menjadi masalah besar yang memerlukan penanganan secara serius. $^{2}$

Obesitas merupakan suatu penyakit multifaktorial, yang terjadi akibat akumulasi jaringan lemak berlebihan. Diabetes Melitus(DM) merupakan salah satu penyakit degeneratif yang disebabkan oleh obesitas. $^{3,4}$ Penyakit lainnya yaitu kardiovaskular, hipertensi, dan penyakit batu empedu. ${ }^{3,5}$ Penduduk dengan obesitas mempunyai risiko terkena DM lebih besar dari penduduk yang tidak obes.Laporan dari World Health Organization (WHO) mengenai studi populasi DM di berbagai negara, jumlah penderita diabetes mellitus pada tahun 2000 di Indonesia menempati urutan ke-4 terbesar dalam jumlah penderita diabetes mellitus dengan prevalensi 8,4 juta 
jiwa. Urutan diatasnya adalah India (31,7 juta jiwa), China (20,8 juta jiwa), dan Amerika Serikat (17,7 juta jiwa). Pada tahun 2010 jumlah penderita DM di Indonesia menjadi 5 juta dan di dunia 239,9 juta penderita. Diperkirakan pada tahun 2030 prevalensi diabetes mellitus di Indonesia meningkat menjadi 21,3 juta.,

Diabetes Mellitus (DM) yang umum dikenal sebagai kencing manis adalah penyakit yang ditandai dengan hiperglikemia (peningkatan kadar gula darah). ${ }^{7}$ Hubungan Obesitas dan Diabetes Mellitus dimana pada orang obes terjadinya penurunan adiponektin dan peningkatkan asam lemak bebas yang berlawanan dengan efek insulin sehingga menyebabkan penurunan sensitivitas insulin (resistensi insulin). Asam lemak dan beberapa metabolit lain mengaktifkan protein kinase dan merusak sinyaling insulin dengan meningkatkan fosforilasi serin yang bersifat inhibisi dari Insulin receptor subsrate (IRS), sehingga menyebabkan resistensi insulin. ${ }^{5,8}$ Pada resistensi insulin, terjadi peningkatan produksi glukosa dan penurunan penggunaan glukosa sehingga mengakibatkan peningkatan kadar gula darah (hiperglikemik). ${ }^{9}$

Pada masa remaja pengaruh teman sebaya lebih menonjol dari pada peran keluarga. Remaja lebih mudah menerima pengaruh globalisasi, pengaruh pola makan "kebarat-baratan" (eropa) dengan tinggi lemak, tinggi kalori dan rendah serat menjadi makanan yang menarik seperti fast food atau junk food. Sekitar 15-20\% remaja Indonesia biasa mengkonsumsi ayam goreng dan burger produk luar negeri dan sekitar $87 \%$ remaja suka makan diluar, seperti es campur, bakso dan jajanan lainya. Pola hidup pasif dan pola makanan yang tinggi lemak, rendah serat, seperti diatas dapat sebagai pemicu peningkatan prevalensi obesitas. ${ }^{10}$

Prevalensi obesitas di Indonesia 2010 adalah 19,1\% dengan prevalensi paling kecil (13\%) adalah provinsi Nusa Tenggara Timur dan prevalensi paling besar $(37,1 \%)$ adalah provinsi Sulawesi Utara. ${ }^{11}$ Minahasa merupakan salah satu kabupaten yang terletak di Sulawesi Utara. Di daerah ini banyak orang mengkonsumsi makanan yang berlemak tinggi dan berserat rendah, sehingga mempunyai resiko tinggi terhadap terjadinya obesitas dan tingginya kadar gula dalam darah. ${ }^{12}$ Pemeriksaan gula darah pada remaja obes penting dalam deteksi dini diabetes mellitus ataupun penyakit degeneratif lainnya.

\section{METODE PENELITIAN}

Metode yang digunakan dalam penelitian ini adalah metode cross sectional deskriptif untuk melihat gambaran gula darah puasa pada remaja obes.

Penelitian ini dilaksanakan pada bulan Agustus 2012 sampai dengan Januari 2013di SMK Negeri yang terletak di kota Tondano. Sampel pada penelitian ini merupakan siswa obes di SMK Negeri Kota Tondano yang berumur 13 sampai 18 tahun dengan jumlah 54 siswa. Pemeriksaan dilakukan melalui 2 cara, dengan pemeriksaan obesitas dan pemeriksaan gula darah puasa padasiswa yang telah berpuasa selama 12 jam atau lebih. Analisa sampel dilakukan di Laboratorium Klinik Manado.

Kriteria obesitas menurut IDF 2005 adalah orang dengan lingkar pinggang $>80$ $\mathrm{cm}$ pada perempuan dan $>90 \mathrm{~cm}$ pada lakilaki. ${ }^{12}$ Dengan kondisi GDP normal $<110$ $\mathrm{mg} / \mathrm{dL}$, GDP TGT <126 mg/dL dan GDP GPT 110-126 mg/dL. Kriteria menurut WHO 2005. ${ }^{13,14}$

\section{HASIL DAN PEMBAHASAN}

Sebanyak 54 siswa yang memenuhi kriteria diperoleh dalam waktu sebulan. Nilai minimum, nilai maksimum, rerata dan standar deviasi ditunjukkan dalam tabel 1 . Nilai maksimum untuk kadar GDP terdapat pada 1 siswa perempuan dengan lingkar pinggang sebesar $86 \mathrm{~cm}$.

Nilai rerata dan standar deviasi usia merupakan 16,3+1,14 dengan usia termuda 14 tahun dan usia tertua 18 tahun. Kadar GDP 82,2+21 dengan kadar terendah 56 $\mathrm{mg} / \mathrm{dL}$ dan tertinggi $205 \mathrm{mg} / \mathrm{dL}$. Pada lingkar pinggang 87,9+7,1 dengan ukuran terkecil $81 \mathrm{~cm}$ dan terbesar $113 \mathrm{~cm}$. 
Tabel 1. Nilai minimum, maksimum, rerata dan standar deviasi variabel penelitian.

\begin{tabular}{|c|c|c|c|}
\hline Variabel & N Min & Maks & $\begin{array}{c}\text { Mean+S } \\
\text { D }\end{array}$ \\
\hline Usia & 5414 & 18 & $16,3 \pm 1,14$ \\
\hline Kadar GDP (mg/dL) & 5456 & 205 & $82,2+21$ \\
\hline $\begin{array}{l}\text { Lingkar Pinggang } \\
(\mathrm{cm})\end{array}$ & 5481 & 113 & $87,9 \pm 7,1$ \\
\hline
\end{tabular}

Dalam penelitian yang dilaksanakan di sekolah menengah di Kota Tondano, penulis mendapatkan dari 54 siswa obes 11 diantaranya merupakan remaja laki - laki dan 43 remaja perempuan. Siswa obes diukur melalui lingkar pinggang menurut IDF 2005 yaitu $>80 \mathrm{~cm}$ pada perempuan dan $>90 \mathrm{~cm}$ pada laki-laki. ${ }^{12}$ Pemeriksaan gula darah puasa untuk menggunakan standar WHO 2005, yaitu dimana kondisi GDP normal $<110 \mathrm{mg} / \mathrm{dL}$, GDP TGT $<126 \mathrm{mg} / \mathrm{dL}$ dan GDP GPT 110-126 mg/dL. ${ }^{13,14}$

Jumlah remaja perempuan lebih banyak daripada laki-laki yaitu sebanyak 43 siswa (79,6\%). Distribusi frekuensi variabel yang diteliti dapat dilihat pada tabel 2 .

Tabel 2. Gambaran gula darah pada remaja obes di SMK Negeri Tondano.

\begin{tabular}{ccccc}
\hline $\begin{array}{c}\text { Jenis } \\
\text { Kelamin }\end{array}$ & N & Normal & $\begin{array}{c}\text { Hiper- } \\
\text { glikemia }\end{array}$ & $\begin{array}{c}\text { Jum- } \\
\text { lah } \\
\mathbf{( \% )}\end{array}$ \\
\hline $\begin{array}{c}\text { Laki - } \\
\text { laki }\end{array}$ & 1 & $11(100 \%)$ & $0(0 \%)$ & 100 \\
$\begin{array}{c}\text { Perem- } \\
\text { puan }\end{array}$ & 3 & 39 & & \\
Total & 5 & $\begin{array}{c}(90,7 \%) \\
50\end{array}$ & $4(9,3 \%)$ & 100 \\
$(92,6 \%)$ & $4(7,4 \%)$ & 100 \\
\hline
\end{tabular}

Pada tabel 2. tampak gambaran gula darah pada remaja obes, diperoleh 4 siswa remaja perempuan atau sebanyak 9,3\% dengan hiperglikemia, dari total 43 siswa perempuan. Sedangkan remaja laki-laki dan remaja perempuan lainnya mempunyai GDP dalam batas normal.

Dari hasil laboratorium diperoleh bahwa 4 remaja obes mengalami hiperglikemia, yaitu sekitar 7,4\% dan dialami oleh remaja perempuan. Hal ini sesuai dengan hasil penelitian yang dilakukan oleh M. Mexitalia di Jawa Tengah dimana terdapat $7,6 \%$ remaja obes dari 79 siswa dengan peningkatan gula darah puasa. ${ }^{15}$

Distribusi lemak tubuh adalah faktor resiko penting terhadap penyakit yang berkaitan dengan obesitas. Proporsi lemak abdominal yang tinggi dikenal sebagai komponen penting dalam resistensi insulin dan DM. Banyak penelitian menunjukkan bahwa lingkar pinggang merupakan indikator antropometri yang baik dalam memprediksi DM tipe 2. Hasil penelitian Z. Wang dan W.E. Hoy pada tahun 2004 menunjukkan bahwa lingkar pinggang merupakan pengukuran tubuh yang paling baik dalam memprediksi DM tipe 2 pada orang Aborigin. Penelitian yang dilakukan Hilary Jane Bambrick pada tahun 2005 menunjukkan bahwa Lingkar Pinggang berhubungan secara signifikan dengan peningkatan kadar Gula Darah Puasa pada laki-laki dan wanita. Hubungan ini tidak sama kuat untuk IMT, jadi distribusi lemak sentral merupakan prediktor yang lebih kuat daripada massa tubuh secara keseluruhan. ${ }^{16}$ Pada penelitian ini juga ditemukan adanya peningkatan gula darah puasa pada remaja dengan obesitas abdominal.

Pada tabel 2 dapat dilihat bahwa peningkatan kadar gula darah puasa terjadi pada 4 siswa peremuan dari keseluruhan siswa. Hal ini dapat disebabkan persentase lemak tubuh perempuan lebih tinggi dibandingkan laki-laki. ${ }^{15}$

Beberapa faktor penyebab obesitas termasuk dalam pola makan, perilaku dan gaya hidup. Masa remaja merupakan masa transisi atau masa peralihan yang ditandai dengan adanya perubahan aspek fisik, psikis dan psikososial. Maka dari itu remaja gampang menerima pengaruh globalisasi, termasuk didalamnya pola makan yang tinggi lemak dan rendah serat seperti fast food atau junk food. Terdapat tiga penyebab obesitas yaitu faktor fisiologis, faktor psikologis dan faktor kecelakaan. Faktor fisiologis adalah faktor yang berasal dari berbagai variabel baik yang bersifat herediter maupun yang bersifat non herediter. Faktor 
psikologis terjadinya obesitas, ialah bagaimana gambaran kondisi emosional yang tidak stabil sehingga cenderung melakukan pelarian diri (self-mechanism defence) dengan cara banyak makan-makanan yang mengandung kalori atau kolesterol tinggi. Faktor Kecelakaan atau Cidera Otak dapat juga menyebabkan obesitas, terjadi karena adanya kerusakan syaraf otak pada pusat rasa lapar yang menyebabkan individu tidak pernah merasa kenyang. ${ }^{10,1}$

Remaja Obes tersebut mengalami akumulasi lemak berlebihan, terlebih lagi lemak viseral pada abdomen. Steven et al, menemukan bahwa subyek dengan peningkatan lemak viseral atau intra-abdominal lebih resisten terhadap insulin daripada subyek dengan peningkatan secara kuantitas dari lemak subkutan di bagian sentral. Akumulasi lemak tubuh sentral dihubungkan dengan resistensi insulin, dimana akumulasi lemak tubuh di perifer memberikan respon metabolik yang kurang dapat menimbulkan gangguan kerja insulin. Hal ini dapat menyebabkan terjadinya kelebihan gula darah (hiperglikemia). ${ }^{16}$

\section{KESIMPULAN}

Sebanyak 7,4\% atau sebanyak 4 siswa dari total 54 siswa yang mengalami peningkatan nilai GDP diatas batas normal (hipergli-kemia) dan dialami pada siswi perempuan.

\section{DAFTAR PUSTAKA}

1. Soetiarto F, Roselinda, Suhardi. Hubungan Diabetes Mellitus dengan Obesitas berdasarkan Index Massa Tubuh dan Lingkar Pinggang. Data Riskesdas [homepage on the Internet]. 2007 [cited 2012 Nov]. Available from: http://isjd.pdii.lipi.go.id/admin/jurnal/38110 3642_0125-9695.pdf.

2. Pamela RD. Overweight dan Obesitas sebagai suatu resiko penyakit degeneratif [homepage on the Internet]. 2011 [updated 2011 Apr 15; cited 2012 Nov]. Available from: http://www.suyotohospital.com/index. php?option=com_content\&view=article\&id $=115$ :overweight-dan-obesitas-sebagai- suatu-resiko-penyakitdegeneratif\&catid=3:artikel\&Itemid $=2$.

3. Sugondo S. Obesitas. Dalam: Sudoyo AW, Setiyohadi B, Alwi IK, Simadibrata M, Setiati S, editor. Buku Ajar Ilmu Penyakit Dalam Jilid III (Edisi V). Jakarta: Internal Publishing, 2009; h.1973.

4. Fauci, Braunwald, Kasper, Hauser, Longo, Jameson, et al. Harrison Manual Kedokteran Jilid Dua. Terjemahan oleh Gunawijaya, Hartono, Julius, Djuantoro, Riana. 2012. Tangerang: Karisma Publishing Group, 1988; h.352.

5. Dewi M. Resistensi Insulin Terkait Obesitas: Mekanisme Endokrin dan Intrinsik Sel [homepage on the Internet]. 2007 [cited 2007 Nov]. Available from: http://repository.ipb.ac.id/bitstream/handle/1 23456789/36062/resensi\%20insulin\%20terk ait\%20obesitas.pdf.

6. Yoga T. Tahun 2030 Prevalensi Diabetes Melitus di Indonesia Mencapai 21,3 Juta Orang [homepage on the Internet]. 2009 [cited 2013 Jan]. Available from: http://www.depkes.go.id/index.php/berita/pr ess-release/414-tahun-2030-prevalensidiabetes-melitus-di-indonesia-mencapai213-juta-orang.html

7. Universitas Muhammadiyah Semarang. Diunduh dari: http://digilib.unimus.ac.id/ files/disk1/124/jtptunimus-gdl-sabaenadin6168-1-babi.pdf Diakses : Januari 2013

8. Setiawan M. Peran Resistensi Insulin, Adiponektin dan Inflamasi pada kejadian Dislipidemia Aterogenik [homepage on the Internet]. 2009 [cited 2012 Nov]. Available from: http://ejournal.umm.ac.id/index.php/ sainmed/article/view/1044.

9. Nugroho AE. Hewan Percobaan Diabetes Mellitus: Patologi dan Mekanisme Aksi Diabetogenik [homepage on the Internet]. 2006 [cited 2012 Nov]. Available from: http://biodiversitas.mipa.uns.ac.id/D/D0704/ D070415.pdf.

10. Universitas Sumatera Utara. Diunduh dari: http://repository.usu.ac.id/bitstream/1234567 89/27522/5/Chapter\%20I.pdf Diakses : Januari 2013

11. Trihono. Riset Kesehatan Dasar [homepage on the Internet]. 2010 [cited 2013 Jan]. Available from: http://www.litbang.depkes. go.id/sites/download/buku_laporan/lapnas_ri skesdas2010/Laporan_riskesdas_2010.pdf

12. Bodhy W, Manampiring AE. Prevalensi Sindroma Metabolik Pada Remaja di Kota Tomohon [homepage on the Internet]. 2011 
[cited 2013 Jan]. Available from: http://repo.unsrat.ac.id/250/1/PREVALENSI _SINDROMA_METABOLIK_PADA_RE MAJA_DI_KOTA_TOMOHON.pdf.

13. Canti. Memahami Pengukuran Kadar Gula Darah [homepage on the Internet]. Nodate [cited 2012 Nov]. Available from: http://www.forkom-jerman.org/index.php? option=com_content\&view=article\&id=100: memahami-pengukuran-kadar-guladarah\&catid=38:konsultasikesehatan\&Itemid=86.

14. World Health Organization. Laboratory Diagnosis and Monitoring of Diabetes Mellitus [homepage on the Internet]. 2002 [cited 2012 Nov]. Available from: http://new.paho.org/hq/index.php?option=co m_docman\&task=doc_view\&gid=16135\&It emid $=$

15. Mexitalia, Utari, Sakundarno, Yamauchi,
Subagio, dan Soemantri. Sindroma Metabolik pada Remaja Obesitas [homepage on the Internet]. 2009 [cited 2013 Jan]. Available from: http://eprints.undip.ac.id/19 103/1/06_mexitalia_sindroma_metabolik.pdf.

16. Yuliasih $\mathbf{W}$. Obesitas Abdominal Sebagai Faktor Resiko Peningkatan Kadar Gula Darah [homepage on the Internet]. 2009 [cited 2012 Nov]. Available from: http://eprints.undip.ac.id/35973/1/229_Wiwi _Yuliasih_G2C005314.pdf.

17. Wulandari dan Zulkaida. Self Regulated Behavior pada Remaja Putri yang Mengalami Obesitas [homepage on the Internet]. 2007 [cited 2013 Jan]. Available from: http://repository.gunadarma.ac.id/ bitstream/123456789/481/1/Tri_Wulan_Anit a_Self_Regulated.pdf. 